CLINICAL PRACTICE

Clinical Images

\title{
Urate Bulla: a Rare Manifestation of Gout
}

\author{
Paul F. Ehlers, $M D^{7}$ and Kip Mihara, $M D^{2,3}$
}

\begin{abstract}
'Department of Emergency Medicine, University of California, San Francisco, CA, USA; ${ }^{2}$ Emergency Department, San Francisco VA Medical Center, San Francisco, CA, USA; ${ }^{3}$ Department of Internal Medicine, University of California, San Francisco, CA, USA
\end{abstract}

KEY WORDS: clinical image; dermatology; rheumatology.

J Gen Intern Med 34(6):1069-70

DOI: $10.1007 / \mathrm{s} 11606-019-04864-4$

(C) Society of General Internal Medicine (This is a U.S. government work and not under copyright protection in the U.S.; foreign copyright protection may apply) 2019

A 91-year-old man with a history of gout presented with A 5 days of painless erythema, paresthesia, and warmth over the palmar distal phalanx of his right 3 rd digit. In the last day, the area developed a blister containing white material that

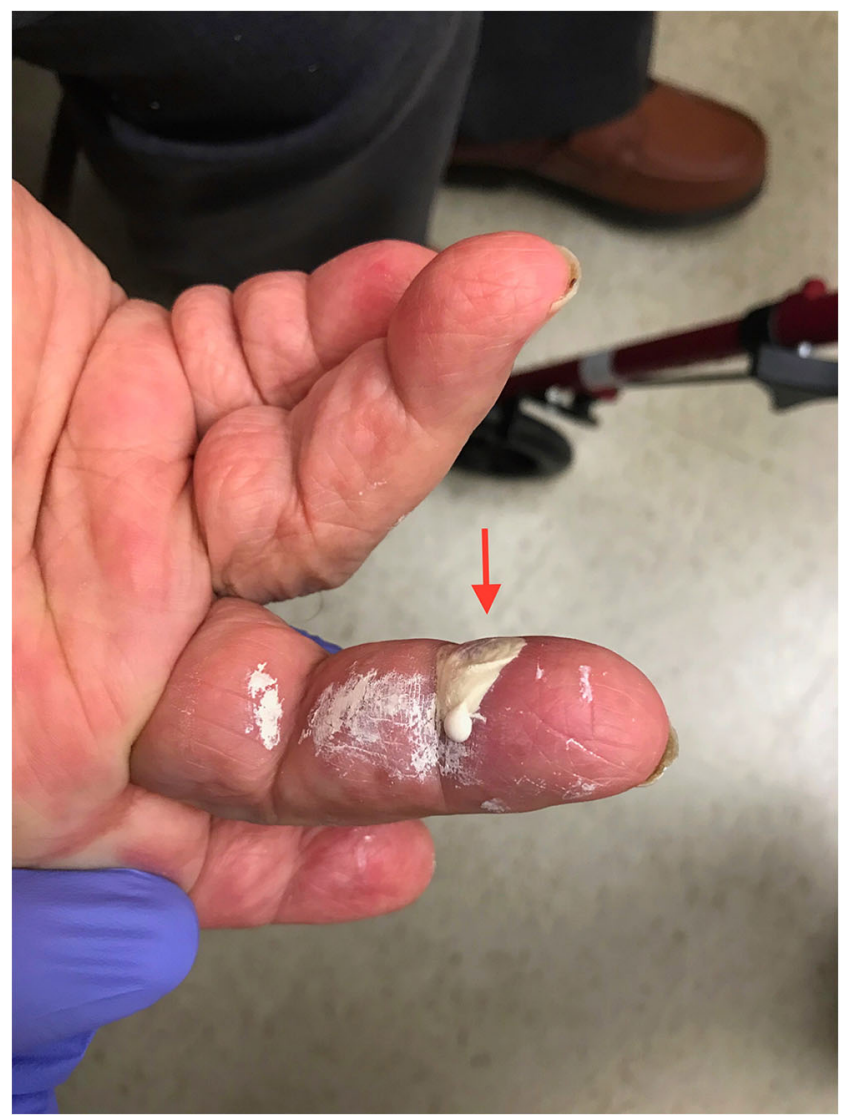

Figure 1 White bulla (red arrow) with chalky material draining, over the palmar distal phalanx of the patient's right 3 rd digit

Received October 19, 2018

Revised December 19, 2018

Accepted January 16, 2019

Published online March 18, 2019

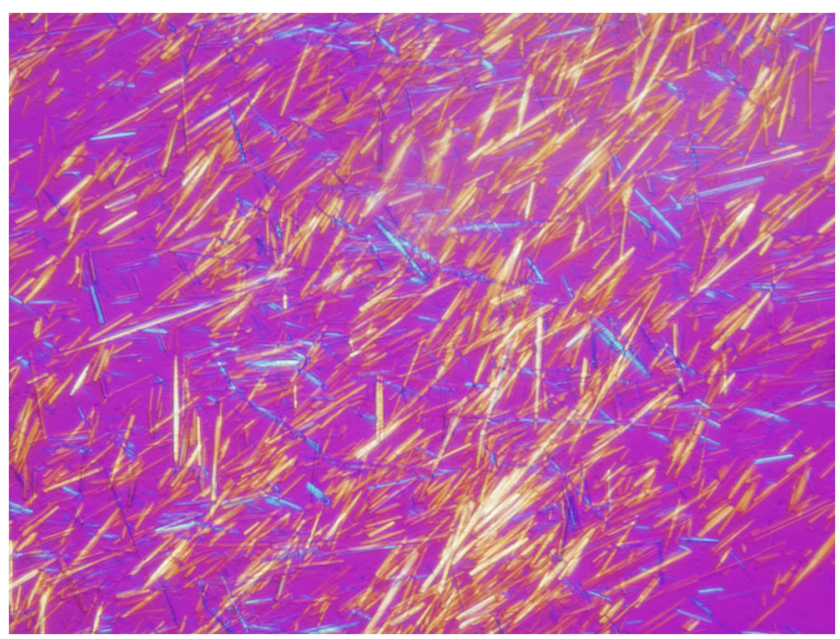

Figure 2 Polarized microscopy of the draining bulla contents, demonstrating negatively birefringent MSU crystals

started draining spontaneously. He had no antecedent trauma or joint pain. On exam, he had a $1.5-\mathrm{cm}$ bulla draining white, chalky material (Fig. 1). There was no pain in the surrounding joints. Polarized light microscopy of the material revealed negatively birefringent needle-like crystals consistent with monosodium urate (MSU) (Fig. 2). Serum uric acid level was $12.2 \mathrm{mg} / \mathrm{dL}$. Milk of urate bulla was diagnosed.

Gout is an inflammatory arthritis caused by deposition of MSU crystals that frequently presents with recurrent acute attacks or with tophi. ${ }^{1,2}$ Very rarely, gout may present with milk of urate bullae which can rapidly form at sites of mild trauma. ${ }^{2,3}$ Although the bulla can be painful and overlie preexisting tophi, it can also be painless and remote to existing inflammatory gouty disease. ${ }^{3}$ Diagnosis is made by polarized light microscopy of the bulla's contents. ${ }^{3}$ Effective treatment may involve drainage of the lesions and urate-lowering therapy. ${ }^{3}$ In this case, the patient was started on allopurinol and colchicine with resolution of the bulla.

Corresponding Author: Kip Mihara, MD; Emergency Department, San Francisco VA Medical Center, San Francisco, CA, USA (e-mail: Kip.mihara@va.gov).

\section{Compliance with Ethical Standards:}

Conflict of Interest: The authors declare that they do not have a conflict of interest. 


\section{REFERENCES}

1. Dalbeth N, Merriman TR, Stamp LK. Gout. Lancet. 2016; 388:2039-52.

2. Robbins RC, Edison, JD. Milk of Urate Bulla. N Engl J Med. 2016; 375:162.
3. Schumacher HR. Bullous Tophi in Gout. Ann Rheum Dis. 1977; 36:9193.

Publisher's Note: Springer Nature remains neutral with regard to jurisdictional claims in published maps and institutional affiliations. 